\title{
Pola Kekuasaan Pendisiplinan dalam Membina Perilaku Peserta Didik di SMA Negeri Olahraga Sriwijaya
}

\author{
Lamtarida Deasy Marice, Ridhah Taqwa \\ ridhotaqwa@fisip.unsri.ac.id, \\ SMA Negeri Olahraga Sriwijaya, Sosiologi FISIP Universitas Sriwijaya \\ The Pattern Of Diciplinary Authority Power In Constructing Students Behavior
In Sriwijaya Sports State High School
}

\begin{abstract}
The research was conducted at Sriwijaya Sports State High School, a special school for students who have talent in the field of sports. The aim is to know the pattern of discipline and the form of disciplinary techniques applied in fostering student behavior. The method used is descriptive qualitative with a case study approach that explores important information about the pattern of application and the form of disciplinary techniques. The data analysis is done by processing and preparing data, reflecting on meaning, processing information, data coding, and making narrative writings. The results of the study show that disciplinary patterns are applied through two mechanisms: first is through supervision (panapticon). This form of supervision takes the form of a point system that has the power to oversee the behavior of students. Other forms of supervision are raids on behavior that violates school rules. Second is the normalization, which is done by applying and enforcing punishment and reward. Disciplinary techniques that are carried out including the use of democratic discipline, permissive discipline, and the application of punishment that is educational in value, but does not lead to a form of violence.
\end{abstract}

Keywords: Supervision, Normalization, Disciplinary Techniques

Received date: 7 Agustus 2019

Article Info

Revised date: 2 Maret 2020

Accepted date: 12 Mei 2020

\section{PENDAHULUAN}

Alat utama untuk mengembangkan kemampuan serta untuk meningkatkan mutu kehidupan dan martabat suatu bangsa menurut Uli (2015) adalah merupakan fungsi utama dari pendidikan. Dalam Undang-Undang No. 20 Tahun 2003 tentang Sistem pendidikan Nasional menjelaskan bahwa pendidikan nasional berfungsi untuk mengembangkan kemampuan dan membentuk watak serta peradaban bangsa yang bermartabat dalam mencerdaskan kehidupan bangsa, bertujuan untuk berkembangnya potensi peserta didik agar menjadi manusia yang beriman dan bertaqwa kepada Tuhan Yang Maha Esa, berakhlak mulia, sehat, berilmu, cakap, kreatif, mandiri, dan menjadi warga Negara yang demokratis serta bertanggung jawab.

Fakta dalam masyarakat bahwa berbagai macam problematika dihadapi bangsa Indonesia dalam pendidikan. Musyaddad (2013: 52) menyatakan bahwa masalah-masalah yang timbul memberikan gambaran tentang tertinggalnya pendidikan bangsa Indonesia dari bangsa-bangsa lain.Hasil kajian United Nations Development Programme (UNDP) dalam laporan Human Development Report 2016 mencatat, Indeks Pembangunan Manusia (IPM) Indonesia pada 2015 berada di peringkat 113, turun dari posisi 110 di 2014. Tahun 2015 IPM Indonesia sebesar 0,689 dan berada di tingkat 113 dari 188 negara di dunia. Dalam 25 tahun terakhir IPM mengalami peningkatan sekitar 30,5 persen. Selain itu, United Nations Development Programme (UNDP) melihat ada beberapa indikator kesenjangan yang bertolak belakang dengan peningkatan IPM diantaranya adalah hampir lima juta anak tidak bersekolah dan anak-anak di Papua memiliki tingkat dikeluarkan dari sekolah yang tinggi. ( https://www.cnnindonesia.com/ekonomi/20170322182446-78-202081/).

Merujuk fakta diatas bahwa pendidikan memiliki peranan terbesar dalam memberikan penyediaan sumberdaya manusia yang memiliki kualitas serta mampu memiliki daya saing yang tinggi. 
Untuk itu diperlukan apresiasi yang tinggi dalam sektor pendidikan (Maliki, 2010: 169). Di Indonesia, berdasarkan pasal 13 dalam Undang-Undang No. 20 Tahun 2003 jalur pendidikan terdiri atas pendidikan formal, nonformal, dan informal. Dan yang dimaksudkan dengan jenjang pendidikan formal terdiri atas tiga jenjang yaitu pendidikan dasar, pendidikan menengah, dan pendidikan tinggi.

Fungsi pendidikan nasional yang tertuang dalam Undang-Undang No.20 Tahun 2003 dapat terlaksana melalui suatu lembaga yang disebut dengan sekolah. Sekolah sebagai lembaga pendidikan yang formal yang diselenggarakan oleh pemerintah. Dan sekolah memiliki beberapa peran seperti yang dituliskan oleh Idi (2011: 142) bahwa sekolah sebagai suatu lembaga yang dirancang untuk pengajaran siswa (atau murid) di bawah pengawasan pendidikan (guru). Dari sisi lain ia menyatakan sebagian besar Negara memiliki sistem pendidikan formal, yang umumnya wajib, dalam upaya menciptakan peserta didik agar mengalami kemajuan setelah pembelajaran.

Artinya sekolah memiliki peranan yang sangat penting dan sebagai sarana yang dibutuhkan oleh masyarakat dalam penyelenggaraan dan pengembangan pendidikan Berjalannya penyelenggaraan dan pengembangan pendidikan tidak terlepas dari peran serta dan dukungan dari pendidik (guru). Guru di sekolah seperti yang dikemukakan oleh Idi (2011: 74) berperan memberikan pengetahuan (knowledge), dan guru memiliki peranan untuk mengajarkan nilai-nilai yang dapat diyakini dan menjadi panutan dan pandangan dalam masyarakat. Sehingga sekolah memiliki kontribusi untuk memberikan pendidikan moral bagi peserta didik. Selain itu masyarakat turut berperan aktif dalam pendidikan sehingga kualitas pendidikan dapat baik. Dengan kualitas pendidikan yang baik tentu menghasilkan peserta didik yang baik.

Kualitas pendidikan di Indonesia sampai saat ini masih belum mampu mencerahkan bangsa, ditandai dengan memudarnya nilai-nilai luhur kemanusiaan dan hancurnya karakter bangsa. Banyaknya berita di media sosial, dan media cetak mengenai perilaku peserta didik mengalami kemerosotan. Sekolah sebagai pusat pendidikan tentu mempersiapkan peserta didik untuk menjadi manusia beradab. Artinya yang diperlukan anak dalam cakupan lebih luas yaitu sebagai sarana pembudayaan dan penyaluran nilai (enkulturasi dan sosialisasi).

Disiplin merupakan salah satu cara yang dilakukan untuk mengajarkan, menanamkan nilai-nilai kepada peserta didik. Penerapan disiplin dilakukan oleh guru dalam membina perilaku peserta didik. Metode hukuman secara sosiologis menurut Martono (2014:85) merupakan cerminan proses penegakan kedisiplinan dan menunjukkan karakter. Pada dasarnya disiplin adalah suatu proses untuk mengubah individu agar dapat bertindak sesuai "harapan". Foucault dalam Martono (2014: 86) melihat pendisiplinan merupakan sebuah mekanisme pembentukan perilaku individu yang taat dan patuh (baca: tubuh yang taat). Pada serangkaian norma melalui sistem kontrol atau pengawasan terhadap individu. Dan pendisiplinan bertujuan agar mampu melakukan secara tepat sesuai yang kita inginkan .

Martono (2014:87) menyebutkan bahwa menurut Foucault pendisiplinan memerlukan kontrol secara khusus pada bagian-bagian tubuh. Fokus kedisiplinan dilakukan melalui cara atau cara lain untuk mencapai hasil melalui serangkaian prosedur yang spesifik. Foucault menyebutkan bahwa tubuh individu mampu menafsirkan suatu perintah, dan mampu meninterpretasikan perintah. Upaya membentuk perilaku tubuh yang taat dan dapat dikendalikan disebut oleh Foucault sebagai mekanisme pendisiplinan. Mekanisme yang dimaksudkan adalah pendisiplinan dapat dibentuk melalui : pertama, "pengamatan (pengawasan) bertingkat" ; kedua, melalui normalisasi (la normalisation) atau standarsasi penilaian. Jardine (dalam Martono, 2014:92) menuliskan pelaksanaan normalisasi diikuti oleh ganjaran dan hukuman; ketiga adalah sebuah ujian atau pemeriksaan.

Pendisiplinan dalam lingkungan sekolah seperti yang dituliskan oleh Foucault mengenai ketepatan waktu, disiplin, kerapian, dan tunduk pada otoritas salah satunya diterapkan oleh sekolah SMA Negeri Olahraga Sriwijaya. SMA Negeri Olahraga Sriwijaya merupakan salah satu sekolah yang khusus diperuntukkan kepada olahragawan (SKO) yang berada di Provinsi Sumatera Selatan dan didirikan pada tahun 2004. Dan dikenal dengan sebutan SONS (Sekolah Olahraga Negeri Sriwijaya). Fungsi sekolah adalah untuk menjaring, membina peserta didik yang memiliki bakat dalam bidang olahraga untuk mencapai prestasi baik di bidang akademis maupun olahraga. Sehingga sekolah berperan untuk membentuk karakter dan mental peserta didik .

Kedisiplinan menjadi sorotan terutama yang dilakukan dalam membina perilaku dan karakter dari peserta didik. Sehingga disiplin selalu dijunjung tinggi oleh peserta didik. Terdapat peraturan- 
Pola Kekuasaan Pendisiplinan dalam Membina Perilaku Peserta Didik di SMA Negeri Olahraga

Sriwijaya (Lamtarida Deasy Marice, Ridhah Taqwa)

peraturan yang ditaati oleh peserta didik selama mengikuti pendidikan. Aktivitas peserta didik setiap harinya dilakukan secara teratur.

Foucault (dalam Martono, 2014: 86) menyebut bahwa disiplin dipandang sebagai sebuah teknologi kekuasaan modern. Dan disiplin memiliki fungsi sebagai pengendali, mengoreksi, mengatur, dan mengawasi tubuh. Artinya bahwa pendisiplinan sebagai mekanisme kekuasaan untuk membentuk tubuh yang terampil dan berguna.

Peserta didik di SMA Negeri Olahraga Sriwijaya berperan sebagai pelajar dan sebagai atlet memiliki dedikasi yang tinggi terhadap disiplin. Tubuh menjadi sasaran utama dalam mekanisme pendisiplinan. Terdapat relasi kekuasaan dalam melaksanakan pendisiplinan yang dilakukan untuk membentuk tubuh yang terampil dan berguna seperti yang dikemukakan oleh Foucault.

Ketepatan waktu, keteraturan, ketaatan harus dilakukan oleh peserta didik. Setiap peraturan harus ditaati oleh peserta didik di lingkungan sekolah, asrama, dan tempat berlangsungnya aktivitas latihan dalam setiap cabang olahraga. Prinsipnya penerapan disiplin dilakukan kepada peserta didik berdasarkan tata tertib sekolah.

Tata tertib yang diberlakukan kepada peserta didik bersifat tegas, ketat, dan mengikat. Peserta didik dalam menjalankan aktivitas sering melakukan beberapa bentuk pelanggaran. Hasil observasi yang dilakukan menunjukkan bahwa bentuk pelanggaran dilakukan oleh peserta didik, dapat dilihat pada tabel 1.1 berikut:

Tabel 1. Bentuk Pelanggaran Tata tertib Peserta Didik SMA Negeri Olahraga Sriwijaya Tahun Pembelajaran 2017-2018

\begin{tabular}{|c|c|c|c|}
\hline \multirow[t]{3}{*}{ No } & \multirow[t]{3}{*}{ Bentuk -Bentuk Pelanggaran } & \multicolumn{2}{|c|}{ Jumlah Pelanggaran } \\
\hline & & Tahun & Tahun \\
\hline & & 2017 & 2018 \\
\hline $\mathbf{l}$ & Absensi/ bolos sekolah tanpa alasan yang jelas & 17 & 9 \\
\hline 2 & $\begin{array}{l}\text { Tidak mengikuti ulangan harian/semester dan tidak } \\
\text { mengerjakan tugas sekolah yang diberikan guru }\end{array}$ & 2 & 3 \\
\hline 3 & Tidak ikut apel pagi & 23 & 15 \\
\hline 4 & Tidak mengikuti latihan fisik & 31 & 10 \\
\hline $\mathbf{5}$ & Tidak memakai atribut sekolah & 15 & 20 \\
\hline 6 & Meninggalkan KBM & 10 & 12 \\
\hline 7 & $\begin{array}{l}\text { Siswa laki-laki mengecat rambut, berambut panjang, } \\
\text { dan bergaya rambut formal pelajar }\end{array}$ & 40 & 16 \\
\hline 8 & Merokok & 3 & 1 \\
\hline 9 & Membawa handphone multimedia & 10 & 14 \\
\hline 10 & $\begin{array}{l}\text { Melawan/tidak mengerjakan tugas-tugas yang } \\
\text { dibenikan pelatih }\end{array}$ & 0 & 1 \\
\hline 11 & $\begin{array}{l}\text { Melawan/tidak mengerjakan tugas-tugas yang } \\
\text { diberikan pengelola asrama }\end{array}$ & 1 & 2 \\
\hline 12 & Meninggalkan asrama tanpa Izin & 1 & 2 \\
\hline 13 & Memiliki, menyimpan gambar/video pomo & 1 & 2 \\
\hline
\end{tabular}

Berdasarkan tabel di atas menunjukkan ada 13 bentuk pelanggaran yang dilakukan oleh peserta didik. Bentuk pelanggaran yang tertinggi pada tahun 2017 adalah siswa laki-laki yang berambut panjang dengan jumlah 40 pelanggaran . Pada tahun 2018 bentuk pelanggaran yang tertinggi adalah peserta didik yang tidak menggunakan atribut sekolah dengan lengkap berjumlah 20 pelanggaran. Masingmasing pelanggaran memiliki jumlah bobot yang berbeda. Setiap tahun peserta didik diberikan point sebanyak 100. Bagi siswa yang melakukan pelanggaran maka bobot yang dimiliki akan berkurang sesuai dengan bentuk pelanggaran yang dilakukan.

Bentuk pelanggaran yang dilakukan oleh peserta didik merupakan bentuk tindakan indispliner. Perilaku dan aktivitas peserta didik secara keseluruhan tidak terlepas dari pengawasan yang dilakukan oleh guru, pengelola asrama, pelatih, dan keamanan. Penerapan disiplin perlu dilakukan dengan mekanisme seperti yang dikemukan oleh Foucault dalam bentuk relasi kekuasaan agar peserta didik dapat berperilaku taat, patuh, dan tepat waktu. 
Berdasarkan latar belakang masalah yang telah di uraikan, maka persoalan yang hendak dikaji dalam penelitian ini adalah bagaimana pola kedisiplinan yang diterapkan kepada peserta didik SMA Negeri Olahraga Sriwijaya dan bagaimana juga bentuk teknik pendisiplinan yang diberikan dalam membina perilaku peserta didik? Penelitian bertujuan untuk mengetahui pola kedisiplinan yang diterapkan kepada peserta didik SMA Negeri Olahraga Sriwijaya dan bentuk teknik pendisiplinan yang dilakukan dalam pembinaan perilaku peserta didik. Dari tujuan tersebut, maka hasil dari penelitian dijadikan rekomendasi kepada para pendidik untuk menentukan kebijakan-kebijakan yang tepat dalam menerapkan mekanisme dan bentuk pendisiplinan yang tepat dalam membina perilaku peserta didik.

\section{KAJIAN PUSTAKA}

Peran sekolah adalah berupaya membentuk karakter peserta didik salah satunya melalui penanaman nilai-nilai kedisiplinan. Disiplin sebagai output dalam pendidikan berguna untuk mendorong peserta didik berperilaku sesuai dengan aturan sehingga diperlukan suatu ketaatan, kepatuhan, dan kesetiaan.

\section{Pola Penerapan Kedisiplinan}

Disiplin menjadi sutau kebutuhan bagi anak seperti yang dituliskan oleh Hurlock (1978:83) kebutuhan yang dapat diisi oleh disiplin diantaranya adalah pertama; melalui disiplin memberi rasa aman dengan dengan memberitahukan apa yang boleh dan yang tidak boleh dilakukan. Kedua; melalui disiplin memungkinkan anak hidup menurut standar yang disetujui kelompok sosial dan dengan demikian memperoleh persetujuan sosial. Ketiga; Melalui disiplin anak dapat belajar menurut cara yang mendatangkan pujian yang akan ditafsirkan anak sebagai tanda kasih saying dan penerimaan. Keempat; disiplin yang sesuai dengan perkembangan berfungsi sebagai motivasi pendorong ego yang mendorong anak mencapai apa yang diharapkan. Kelima; disiplin membantu anak mengembangkan hati nurani ("suara dari dalam") pembimbing dalam pengambilan keputusan dan pengendali perilaku.

Menurut Foucault (dalam Hardiyanta, 1997: 92) disiplin sebagi seni latihan yang benar dengan fungsi utama melatih. Sehingga individu menjadi elemen patuh dan berguna. Dan disiplin memilah menjadi elemen yang tidak seragam dan mengubah prosedurnya menjadi unit tunggal yang memadai. Disiplin akan membentuk individu-individu. Serta menurut Foucault disiplin merupakan teknik kuasa yang menempatkan individu sebagai objek serta sekaligus merupakan bagian dari perangkat pelaksanaan mekanisme-mekanisme.

Pola penerapan disiplin yang dimaksud adalah standarisasi yang dipergunakan dalam melaksanakan penerapan disiplin untuk melatih peserta didik sesuai dengan norma, peraturan tata tertib yang berlaku di sekolah. SMA Negeri Olahraga Sriwijaya merupakan sekolah berpola asrama yang segala aktivitas peserta didik di lingkungan sekolah, lingkungan asrama, lingkungan tempat latihan memiliki keterkaitan yaitu antara sekolah, asrama, dan tempat latihan. Setiap aktivitas kegiatan para peserta didik dalam sekolah, asrama dan tempat latihan sebagai lingkup bagian dari peraturan dari tata tertib yang berlaku dan harus ditaati semua peserta didik.

\section{Pembinaan Perilaku}

Pembinaan menurut Hadiawati (2008:19) adalah proses perbuatan, pembaharuan, penyempurnaan, usaha, tindakan, dan kegiatan yang dilakukan secara terus menerus untuk memperoleh hasil yang lebih baik. Arifin dalam Srijatun (2012:33) perilaku adalah cerminan kepribadian seseorang yang tampak dalam perbuatan dan interaksi terhadap orang lain dalam lingkungan sekitarnya. Perilaku merupakan internalisasi nilai-nilai yang diserap oleh seseorang selama proses berinteraksi dengan orang lain diluar dirinya. Perilaku seseorang menunjukkan tingkat kematangan emosi, moral, agama, sosial, kemandirian dan konsep dirinya. Perilaku manusia terbentuk selama perjalanan kehidupannya.

Pembinaan perilaku yang dimaksudkan adalah upaya yang dilakukan oleh sekolah dalam menerapkan kedisiplinan kepada peserta didik. Sehingga terjadi suatu proses yang mengarahkan untuk memperoleh perubahan bagi peserta didik dalam hubungan sosial baik dalam lingkungan sosialnya. Pembinaan perilaku merupakan menjadi cara utama dalam membentuk dan mempengaruhi perilaku peserta didik berinteraksi. 
Pola Kekuasaan Pendisiplinan dalam Membina Perilaku Peserta Didik di SMA Negeri Olahraga

Sriwijaya (Lamtarida Deasy Marice, Ridhah Taqwa)

\section{Mekanisme Pendisiplinan}

Mekanisme pendisiplinan menurut Foucault dapat diuraikan sebagai berikut:

\section{Pengamatan (pengawasan) melalui panopticon}

Foucault menyatakan panoptticism adalah suatu model teknologi disiplin yang dapat berbentuk dalam metode-metode atau sarana-sarana keras dan ketat seperti yang dirancang oleh J. Bentham dengan model arsitektural. Melalui panoptikon disiplin menjadi suatu fungsi dalam keseluruhan tubuh sosial. Sehingga panoptikon sebagai relasi disiplin. (Foucault dalam Hardiyanto, 1997:114). Dalam pendidikan di sekolah mekanisme panoptikon dapat memberikan kemudahan kepada guru untuk mengawasi aktivitas muridnya. Menurut Wain dalam Martono (2014:113) bentuk panoptikon merupakan bentuk sistem pengawasan modern di sekolah. Ada beberapa bentuk sistem panoptikon diantaranya adalah: sistem pendaftaran, pengarsipan laporan kemajuan akademik, memakai seragam sesuai standar, menaati tata tertib, penggunaan jadwal yang ketat.

\section{Mekanisme standardisasi (la Normalisation)}

Standarsisasi yang dimaksudkan adalah cara yang digunakan untuk mengukur, mengelompokkan, dan menggategorikan individu sesuai standar atau norma tertentu. (Alan dalam Martono, 2016: 11). Foucault dalam Martono (2016: 11) menyatakan bahwa dalam standardisasi individu dinilai tidak hanya dari kebaikan dan kesalahan yang dilakukannya, namun individu dinilai dengan menggunakan standar tertentu. Wujud standadrisasi perilaku siswa adalah dalam bentuk tata tertib sekolah.

Melalui tata tertib, sekolah dapat mengklasifikasikan antara siswa yang patuh, siswa membangkang, siswa yang tidak disiplin, siswa yang berhak mendapat pujian, dan mana siswa yang layak mendapat hukuman.

\section{METODE PENELITIAN}

Penelitian ini mempergunakan strategi penelitian studi kasus dengan unit analisis yaitu SMA Negeri Olahraga Sriwijaya. Dipilihnya sekolah tersebut dengan pertimbangan sebagai sekolah yang dikhususkan untuk peserta didik yang memiliki bakat dan prestasi tinggi dalam bidang olahraga. Disisi lain sebagai sekolah yang berperan membentuk karakter dan mental peserta didik untuk memiliki kedisiplinan yang tinggi. Informan penelitian ini berjumlah 16 orang yang terdiri terdiri dari 10 orang guru, 3 orang pelatih, 2 orang pengurus asrama, dan 1 orang petugas keamanan sekolah. Teknik analisa dilakukan dengan beberapa tahap yaitu: membuat transkrip wawancara, merefleksi makna dari informasi yang diperoleh, melakukan coding semua data, membuat naratif dari olahan data yang diperoleh.

\section{HASIL DAN PEMBAHASAN}

\section{Tipologi Pendidikan di SMA Negeri Olahraga Sriwijaya Penerapan Kurikulum Sekolah}

Hasil wawancara yang dilakukan kepada wakil kepala sekolah diperoleh informasi bahwa pengelompokkan siswa berdasarkan bakat dan memiliki prestasi dalam bidang olahraga. Penerimaan peserta didik berdasarkan kriteria yang dilakukan dan ditetapkan oleh Dinas Pemuda dan Olahraga (DISPORA) Sumatera Selatan. Penerapan pembelajaran berbeda dengan sekolah lain pada umumnya.

Foucault (dalam Martono, 2016: 93) menyebutkan bahwa sekolah menerapkan sistem seleksi untuk dapat memilih atau memilah individu yang dikatakan layak untuk dapat menikmati pendidikan di tempat mereka. Pernyataan Foucault memberikan suatu gambaran bahwa dalam mekanisme seleksi penerimaan masuk sekolah tentu menjadi suatu mekanisme bekerjanya yang disebut dengan kekuasaan dalam pendidikan

Model pendidikan yang diterapkan kepada peserta didik dengan pengembangan pendidikan umum dan pendidikan kekhususan olahraga. Penyelenggaraan pendidikan yang berlaku di SMA Negeri Olahraga Sriwijaya sesuai dengan kurikulum nasional yaitu Kurikulum 2013 (K-13) dan Kurikulum tingkat satuan pendidikan (KTSP) tahun 2006. Dalam penerapan satu jam pelajaran dengan durasi 35 menit. Normalisasi dan regulasi yang diterapkan di sekolah sebagai arena suatu otoritas pihak sekolah yang dioperasikan. Dominasi tersebut melalui mekanisme kebijakan yang di buat oleh pihak-pihak yang berkepentingan di sekolah. Posisi pihak lebih tinggi dalam hal ini sebagai subyek yaitu kepala sekolah dan wakil kepala sekolah bagian kurikulum memiliki power (kekuasaan) untuk menetapkan 
jam belajar bagi siswa atlet. Dominasi pengetahuan yang dimiliki oleh subyek dengan wacana bahwa beban latihan fisik dan teknis dari siswa atlet yang besar memberikan perbedaan dalam penetapan durasi/ waktu untuk satu matapelajaran yang berlaku di sekolah. Foucault dalam Hidayat (2011: 162) kekuasaan selalu terartikulasikan melalui pengetahuan dan pengetahuan memiliki efek kekuasaan. Artinya penyelenggaraan yang disebut kekuasaan selalu memproduksi pengetahuan sebagai basis dari kekuasaannya yaitu pihak yang terlibat dalam penentapan kurikulum.

\section{SMA Negeri Olahraga Sebagai Sekolah Berpola Asrama}

Dari hasil wawancara yang diperoleh peneliti, penyelenggaraan pendidikan di SMA Negeri Olahraga Sriwijaya dengan menggunakan sistem sekolah berpola asrama atau disebut boarding school. SMA Negeri Olahraga Sriwijaya menerapkan sistem boarding school yang bertujuan sebagai pemusatan latihan dan menjadikan peseta didik dapat berkonsentasi secara penuh. Peserta didik memiliki status sebagai atlet yang aktivitas kegiatan latihan fisik dan latihan teknik yang dilakukan sebagai suatu kebiasaan (folkways). Kebiasaan yang dilakukan dengan teratur oleh setiap peserta didik.

Sistem boarding school SMA Negeri Olahraga Sriwijaya berdasarkan jenis kelamin. Peserta didik yang laki-laki tinggal di asrama putera, dan peserta didik perempuan tinggal di asrama puteri. Jumlah kamar di setiap asrama baik asrama putera dan asrama puteri berjumlah 22 kamar. Pembagian kamar di asrama dikelompokkan berdasarkan cabang olahraga.

Pelaksanaa aktivitas atau kegiatan peserta didik di asrama dilakukan secara rutin dimulai hari Senin sampai dengan hari Sabtu. Peserta didik harus patuh sehingga setiap hari secara rutin melakukan aktivitas sesuai dengan jadwal. Melalui jadwal yang telah ditetapkan dapat menjadikan peserta didik memiliki keteraturan dalam melaksanakan aktivitas kegiatan. Setiap hari peserta didik memulai aktivitas mulai pagi hari pukul 04.00 dan aktivitas berakhir hingga pukul 21.30. Rutinitas yang dilakukan mengarahkan peserta didik untuk patuh, dan terlatih sehingga tumbuh kesadaran dalam diri dan bertanggung jawab .

\section{Aktivitas Kegiatan Religius}

Visi dari SMA Negeri Olahraga Sriwijaya adalah terbangunnya bibit-bibit atlet berbakat yang memiliki potensi prestasi tinggi dikalangan pelajar berlandaskan tidak hanya IPTEK akan tetapi kepada IMTAQ. Indikator dari IMTAQ yang dimaksudkan adalah unggul dalam pembinaan ibadah dan unggul dalam pembinaan akhlak. Realisasi kegiatan religius tersebut diwujudkan dalam kegiatan aktivitas dari peserta didik dalam proses pembelajaran di sekolah dan di lingkungan asrama sekolah.

Bentuk kegiatan religius dilakukan oleh peserta didik berdasarkan hasil observasi dan wawancara yang dilakukan di antaranya adalah : membaca Alquran setiap hari, sholat berjemaah. Pelaksanaan kegiatan religius dilakukan dengan pengawasan guru pendidikan Agama Islam dan pengurus asrama. sekolah menerapkan aktivitas kegiatan religius yang mengarah kepada pembinaan akhlak dan meningkatkan keimanana dan ketaqwaan peserta didik. Cara-cara yang dilakukan adalah dengan keterlibatan anak dalam pengajian, sholat jemaah, dan ceramah keagamaan. Pelaksanaan kegiatan dapat terlaksana sehingga perilaku dan kehadiran peserta didik dikontrol lansung oleh pengurus asrama dan pembina pengajian. Akhlak yang baik tentu membentuk karakter peserta didik yang sesuai dengan aturan-aturan yang berlaku dalam masyarakat. Melalui pembinaan religius dapat melatih peserta didik untuk taat dan patuh terhadap ajaran keagamaan. Tentu menumbuhkan kesadaran peserta didik untuk melaksankan ibadah secara teratur.

\section{Aktivitas Kegiatan Waktu Luang}

Hasil wawancara yang dilakukan penulis dengan pengurus asrama disimpulkan bahwa kegiatan minggu bersih seperti : melakukan kerja bakti membersihkan asrama, mushola, ruang makan, dan lingkungan pekarangan asrama. Teknik tersebut dipergunakan oleh pengurus asrama untuk melatih peserta didik untuk menggunakan ketepatan pemanfaatan waktu luang dan keteraturan aktivitas kegiatan.

Teknik tersebut merupakan bentuk paksaan fungsional yang diberikan oleh pengurus asrama dengan sejumlah tuntutan agar peserta didik menjalankan aktivitas yang telah dijadwalkan. Nilai-nilai positif seperti kepedulian, kebersamaan (solidaritas) yang akan menjadikan peserta didik terlatih, sehingga akan membentuk perilaku peserta didik. 
Pola Kekuasaan Pendisiplinan dalam Membina Perilaku Peserta Didik di SMA Negeri Olahraga

Sriwijaya (Lamtarida Deasy Marice, Ridhah Taqwa)

\section{Pola Pengawasan Dalam Pembinaan Perilaku Peserta Didik: Bentuk Kedisiplinan Peserta Didik}

Sekolah merupakan satuan pendidikan yang berupaya untuk melakukan pembinaan terhadap peserta didik agar berperilaku teratur dan terarah. Peserta didik berperilaku sesuai dengan tata tertib. Tata tertib sebagai seperangkat peraturan seluruh tingkah laku siswa selama mereka bersekolah dan berguna untuk menciptakan suasana mendukung pendidikan (Departement Pendidikan dan Kebudayaan dalam Akbal dan Rusnaeni, 2017: 17).

Melalui tata tertib dapat mendorong peserta didik untuk berdisiplin. Kedisiplinan sebagai kondisi yang dapat tercipta dan terbentuk melalui proses dan serangkaian perilaku yang didalamnya memuat beberapa nilai-nilai seperti ketaatan, kepatuhan, kesetiaan, keteraturan dan ketertiban. Nilainilai tersebut menjadi bagian sebagai peserta didik sebagai warga sekolah untuk bertingkah laku (Soegeng P dalam Tu'u, 2004: 31).

Hasil penelitian dari kedisiplinan peserta didik sebagai seorang atlet dilakukan melalui kontrol aktivitas dengan pengaturan untuk mengikuti pelaksanaan latihan-latihan. Relasi yang terbangun dapat menjadikan peserta didik sebagai seorang atlet andalan dan memajukan perkembangan karier sebagai seorang atlet. Pernyataan diatas sejalan dengan pemikiran Foucault (1997:84) bahwa terdapat penembusan kuasa waktu terhadap tubuh, maka dapat terjadi apa yang disebut sebagai "penaklukan" terhadap tubuh.

Tubuh peserta didik dapat terlatih dan berguna apabila dilakukan dengan keteraturan dan ketepatan waktu mengikuti latihan fisik dan latihan cabang olahraga yang dikontrol oleh pelatih fisik dan masing-masing pelatih setiap cabang olahraga. Selanjutnya peserta didik di evaluasi secara berkala dalam jangka waktu 4 bulan sekali mengikuti test berkala dan test akhir periode olahraga. Tujuan dari test yang diberlakukan adalah untuk melihat perkembangan dan kemajuan prestasi olahraga yang dimiliki oleh siswa atlet untuk mendapat pembinaan berkelanjutan.

Hasil wawancara yang diperoleh peneliti, bentuk kedisiplinan peserta didik tidak hanya kedisiplinan dalam mengikuti latihan namun dalam bentuk kedisiplinan mengikuti pembelajaran. Pembelajaran merupakan dimensi utama untuk meningkatkan pengetahuan peserta didik dalam bidang akademik. Kedisiplinan dalam bentuk ketepatan waktu untuk mengikuti pembelajaran. Sebelum masuk mengikuti pembelajaran di kelas peserta didik wajib untuk mengisi daftar kehadiran sebagai tanda bukti kehadiran. Daftar kehadiran akan mengontrol kehadiran jam datang ke sekolah dan pulang sekolah. Melalui daftar kehadiran memberikan makna bahwa perilaku peserta didik dalam bentuk pengawasan dan pengendalian yang dilakukan oleh sekolah .

Bentuk kedisiplinan di asrama berdasarkan wawancara kepada pengurus asrama apabila peserta didik mematuhi larangan dan menjalankan kewajiban sebagai penghuni asrama. Keteraturan dalam menjalankan aktivitas sesuai dengan aturan yang berlaku dalam lingkungan asrama. Aturan untuk menjalankan kewajiban dan menjauhkan peserta didik dari larangan akan menempatkan sebagai individu yang taat, teratur, dan patuh. Larangan dapat menjadi penghindaran untuk melakukan penyimpangan perilaku dari peserta didik.

Kedisiplinan menuntut keteraturan, kepatuhan, dan ketaatan dari peserta didik dalam menjalankan aktivitas kegiatan dalam lingkungan sekolah, asrama, dan tempat latihan. Terciptanya keteraturan, kepatuhan, dan ketaatan dapat menciptakan peserta didik yang memiliki kedisiplinan. Berjalannya kedisiplinan memerlukan yang disebut dengan pengawasan. Secara sosiologis konsep pengawasan terlihat dari kegiatan yang dilakukan oleh individu atau oleh otoritas publik (Karakehya,dkk dalam https://docplayer.biz.tr/18708307-Neden-gozetl-en-iyoruz.html).

\section{Penerapan Sistem Poin di SMA Negeri Olahraga Sriwijaya Sebagai Bentuk Panapticon}

Penerapan dari sistem point dapat disimpulkan berdasarkan hasil wawancara dan observasi yang dilakukan berguna selain untuk mencegah terjadinya pelanggaran, membatasi perilaku indisipliner yang dilakukan peserta didik. Disisi lain sistem poin memberikan ketegasan terhadap peserta didik yang melakukan pelanggaran. Setiap pelanggaran yang dilakukan oleh peserta didik ditindak lanjuti sesuai dengan peraturan yang berlaku di sekolah SMA Negeri Olahraga Sriwijaya. Sehingga peserta didik harus taat, patuh terhadap setiap aturan yang berlaku di sekolah agar menjadi peserta didik yang memiliki kedisiplinan yang tinggi. Kedisiplinan sebagai seorang siswa dalam proses pembelajaran di kelas, kedisiplinan sebagai seorang atlet yang harus memiliki kemajuan dalam prestasi olahraga, kedisiplinan peserta didik di asrama sekolah. 
Pelaksanaan disiplin mempergunakan teknik melalui "pemantauan" yang menyiapkan suatu pengetahuan baru mengenai manusia. Foucault mengibaratkan dengan bangunan. Tujuan dibuatkan bangunan untuk mengawasi individu, membuat individu dapat diketahui dan menjadikan individu tersebut patuh (Foucault dalam Hardiyanto, 1997: 93). Istilah tersebut dikenal dengan sebutan "panopticism".

Foucault lebih mendalam menyebutkan bahwa panapticom dapat menyebabkan tumbuhnya kesadaran dan visibiltas seperti yang terjadi dengan narapidana di penjara, dan panapticom menunjukkan berfungsinya kekuasaan secara otomatis dan seolah-olah permanen (Martono,2014:90). Demikian halnya di sekolah sebagai lembaga pendidikan seperti yang dikemukakan oleh Idi (2014: 74) memiliki fungsi diantaranya dapat memberikan pendidikan dan mengajarkan nilai-nilai kebajikan, mengenai kedisiplinan. Terlaksananya penanaman nilai-nilai kedisiplinan di sekolah memerlukan pengawasan sehingga peserta didik dapat disebut sebagai individu yang memiliki kedisiplinan yang tinggi. Pada perkembangannya mekanisme pengawasan untuk peserta didik di sekolah dapat dilakukan melalui penerapan sistem poin yang diibaratkan sebagai panoptikon atau yang disebut dengan pengawasan atau pemantauan dengan menggunakan istilah yang dikemukakan oleh Foucault.

Dengan merujuk konsep Foucault memberikan pemahaman panaptikon sebagai alat untuk mengawasi mekanisme dari disiplin sendiri dengan di bawah pengawasan maka dapat menilai individu secara terus-menerus, mengubah perilaku, dan memaksakan individu dengan metode yang terbaik.

Penerapan sistem poin yang diberlakukan kepada peserta didik juga berdasarkan hasil wawancara yang dilakukan dapat menjadi alat (tools) untuk mengawasi dan memantau perilaku dari peserta didik secara terus menerus.

Penerapan sistem poin peserta didik sebagai cara yang dilakukan untuk dapat membangun relasi sesuai dengan aturan-aturan yang berlaku di lingkungan sekolah, asrama sekolah, dan tempat di mana peserta didik melakukan latihan-latihan agar dapat menjadi peserta didik yang tidak hanya berbakat dalam olahraga tetapi memiliki prestasi akademik.

Sistem poin yang diberikan kepada peserta didik memiliki bobot 100 yang berlaku selama 1 (satu) tahun. Setiap pelanggaran memiliki bobot yang berbeda. Pembobotan sistem poin bersifat mengikat peserta didik di SMA Negeri Olahraga Sriwijaya. Pembobotan Sistem poin di tanda tangani oleh peserta didik di atas materai yang artinya memiliki kekuatan secara resmi (legal) dan orang tua menyetujui isi dari pembobotan poin pelanggaran tersebut dan kesepakatan tersebut di ketahui oleh kepala sekolah. Setiap pelanggaran yang dilakukan oleh peserta didik mengalami pengurangan poin. Pelanggaran yang dilakukan akan dihitung secara keseluruhan dan apabila pelanggaran yang dilakukan oleh peserta didik telah mencapai total 100 poin sesuai dengan kesepakatan yang telah di tanda tangani peserta didik peserta didik harus bersedia pindah dari sekolah dan secara admisntratif di tarik kembali oleh orang tua.

Penerapan sistem poin dapat menjadi salah satu bentuk mekanisme disiplin seperti yang dimaksudkan oleh Foucault dalam Ball. Sistem poin sebagai mekanisme disipin dapat meningkatkan pelaksanaan kekuasaan yang memberikan keefektifan mengatur, mengontrol, mengawasi, dan memantau perilaku peserta didik dalam keseluruhan aktivitas kegiatan peserta didik serta dapat menjadikan paksaan untuk berperilaku sesuai dengan tata tertib sekolah. Aktivitas tersebut termasuk dalam kegiatan peserta didik meliputi; di sekolah, di tempat latihan, dan lingkungan asrama.

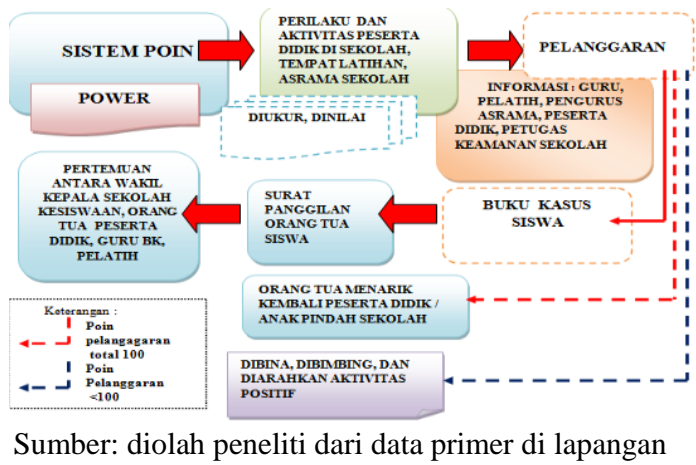

Gambar 1. Bagan Mekanisme Kedisiplinan Peserta Didik SMA Negeri Olahraga Sriwijaya Melalui Penerapan Sistem Poin 
Penerapan dari sistem point dapat disimpulkan berguna selain untuk mencegah terjadinya pelanggaran, membatasi perilaku indisipliner yang dilakukan peserta didik akan tetapi sistem poin memberikan ketegasan terhadap peserta didik yang melakukan pelanggaran. Setiap pelanggaran yang dilakukan oleh peserta didik ditindak lanjuti sesuai dengan peraturan yang berlaku di sekolah SMA Negeri Olahraga Sriwijaya. Sehingga peserta didik harus taat, patuh terhadap setiap aturan yang berlaku di sekolah agar menjadi peserta didik yang memiliki kedisiplinan yang tinggi. Kedisiplinan sebagai seorang siswa dalam proses pembelajaran di kelas, kedisiplinan sebagai seorang atlet yang harus memiliki kemajuan dalam prestasi olahraga, kedisiplinan peserta didik di asrama sekolah.

\section{Pelaksanaan Razia Terhadap Peserta Didik}

Pengawasan perilaku peserta didik dalam bentuk pemantauan dapat dilakukan adalah melalui razia. Hasil penelitian menunjukkan terdapat dua bentuk metode razia dapat memberikan keefektifan untuk mengurangi terjadinya pelanggaran di SMA Negeri Olahraga Sriwijaya. Hasil dari razia peserta didik, ditempatkan dengan kategori yaitu sebagai berikut: peserta didik yang sudah berperilaku sesuai dengan aturan yang berlaku di sekolah disebut sebagai siswa yang memiliki kedisiplinan dan peserta didik yang berperilaku tidak sesuai dengan aturan yang berlaku di sekolah disebut siswa indisipliner. Sehingga razia memungkinkan untuk menciptakan suatu bentuk disiplin dimana perilaku peserta didik dipantau dalam lingkungan sekolah dan lingkungan asrama.

Pelaksanaan razia dilakukan sebanyak 1 (satu) kali dalam 1 (satu) bulan. Subyek pelaksanaan razia adalah oleh guru BK dan guru lain.Penerapan razia kepada peserta didik menurut hasil wawancara dengan wakil kepala sekolah dan guru BK adalah sebagai berikut: pertama; razia secara rutin 1 (satu) bulan dilaksanakan 2 (dua) kali. Kedua; razia yang dilaksanakan pemantauan dari orang lain/ laporan dari guru, pelatih, peserta didik, dan petugas keamanan.

Bentuk razia yang dilakukan kepada peserta didik berdasarkan hasil wawancara dengan informan adalah pertama; razia kelengkapan atribut seragam sekolah. Kedua; razia rambut untuk peserta didik laki-laki yang berambut panjang. Ketiga; razia sepatu berwarna yang dipakai oleh peserta didik. Keempat; razia handphone multimedia atau android. Kelima; razia terhadap zat mengandung nikotin. Keenam; razia buku bukan mata pelajaran. Lebih jelasnya beberapa bentuk razia dapat dilihat dalam bagan berikut:

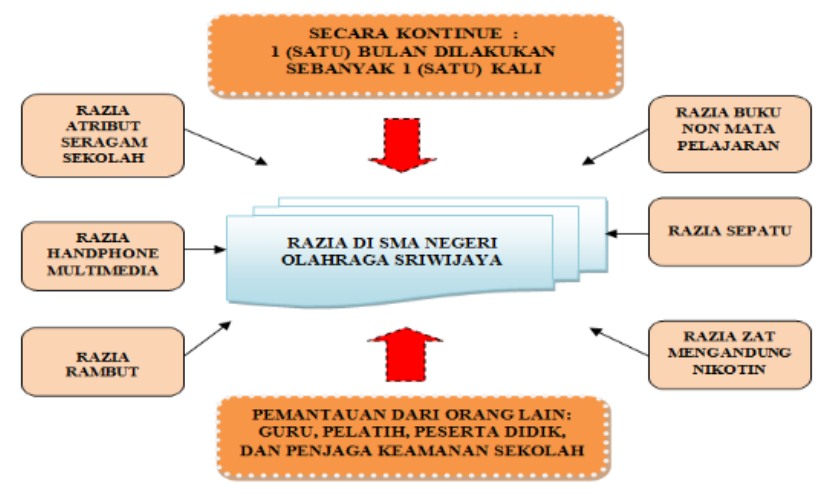

Sumber: diolah peneliti dari data primer di Lapangan

Gambar 2. Bagan Bentuk dan Metode Pelaksanaan Razia Peserta Didik

\section{Penerapan Normalisasi Dalam Pembinaan Perilaku Peserta Didik}

Praktik pendisiplinan kepada peserta didik selain melalui beberapa bentuk yang telah diulas dibagian terdahulu, dapat juga diterapkan dengan menggunakan hukuman (punishment) dan penghargaan (reward). Menurut Foucault (dalam Hardiyanto, 1997: 98) bahwa:

"hukuman bersumber dari mekanisme normalisasi. Dan normalisasi dapat menjadi perangkat kuasa seperti pemantauan. Kuasa normalisasi menghasilkan "keserupaan" dan disisi lain normalisasi dapat "mengindividualisasikan" individu dengan menciptakan jarak yang membatasi, menentukan tingkat, menentukan spesialisasi dan mengubah perbedaan menjadi berguna dengan membuat cocok yang satu terhadap yang lain. Sehingga dalam bentuk "aturan " norma memiliki fungsi untuk menampilkan seluruh bayangan perbedaan individual di dalam sistem kesamaan formal." 
Pernyataan dari Foucault di atas memiliki keterkaitan pendisiplinan yang terjadi di sekolah. Hasil penelitian yang dilakukan bahwa kuasa normalisasi yang dimaksudkan adalah peraturan yang berlaku di sekolah dapat menjadi seperangkat norma untuk mengatur perilaku peserta didik di SMA Negeri Olahraga Sriwijaya. Setiap perilaku peserta didik harus dapat menyesuaikan dengan aturan atau tata tertib yang berlaku di sekolah. Praktik pendisiplinan dapat dilakukan dengan hukuman (punishment) dan penghargaan (reward). Bentuk punishment dan reward yang diberikan kepada peserta didik merupakan bentuk pendisiplinan berfungsi yang menurut Foucault (dalam Martono, 2016: 10) :

"disiplin berfungsi untuk mengendalikan, mengoreksi, mengatur, dan mengawasi tubuh menggunakan norma sebagai sistem."

Hasil wawancara yang dilakukan oleh peneliti dengan guru, pelatih, dan pengurus asrama menyatakan bahwa bentuk punishment yang diterapakan kepada peserta didik adalah : pertama; fisik seperti : dijemur, push up, roll, jogging, lari, mengumpulkan sampah, dan memotong rambut siswa dengan tidak teratur. Kedua; non fisik seperti : teguran, peringatan, nasehat, penyitaan barang. Disisi lain bentuk reward yang dilakukan dalam bentuk material berupa hadiah, imbalan/uang saku. Reward berupa non material berupa pujian, penghormatan, penambahan poin nilai, dan pemberian dispensasi latihan

Melalui punishment yang di terapkan oleh guru, pelatih bertujuan untuk peserta didik dapat mengoreksi bahwa perilaku yang dilakukan telah melanggar peraturan yang berlaku di sekolah. Penerapan punishment disisi yang berbeda dapat disimpulkan dapat menyebabkan terjadinya penggelompokkan peserta didik menjai dua kelompok yaitu: yang termasuk sebagai peserta didik yang patuh dan peserta didik yang tidak patuh.

\section{Teknik Pendisiplinan Dalam Pembinaan Perilaku Peserta Didik}

Pembinaan terhadap perilaku peserta didik merupakan salah satu peran yang dilakukan oleh pendidik. Upaya yang dilaksanakan dalam pembinaan perilaku peserta didik agar sesuai dengan tata tertib atau aturan yang berlaku dapat dilakukan dengan teknik pendisiplinan.

Hasil wawancara yang dilakukan oleh peneliti diperoleh bahwa SMA Negeri Olahraga Sriwijaya menerapkan teknik disiplin demokratis dan disisi lain dilakukan penerapan teknik pendisiplinan otoriter. Pengendalian yang dilakukan pihak sekolah SMA Negeri Olahraga Sriwijaya terhadap pelanggaran yang dilakukan oleh peserta didik adalah dengan memberikan teguran, nasehat, dan pemahaman kepada peserta didik dan apabila masih mengulangi pelanggaran hukuman yang diberikan oleh pihak sekolah adalah berupa penyitaan terhadap handphone multimedia yang dimiliki oleh peserta didik.

Teknik disiplin demokratis juga diterapkan dalam menghadapi peserta didik yang melakukan pelanggaran yang jumlah poin pelanggaran yang dilakukan peserta didik banyak. Upaya yang dilakukan dalam penyelesaian pelanggaran peserta didik tersebut adalah dengan mengadakan dalam forum rapat guru. Secara bersama-sama memberikan keputusan yang tepat dan tegas terhadap pelanggaran yang dilakukan oleh peserta didik. Dan dengan melibatkan pelatih, dan pengurus asrama sekolah. Setiap perilaku peserta didik dikontrol melalui punishment dan reward yang secara proporsional. Terjadi perubahan perilaku peserta didik karena memiliki kesadaran untuk mengikuti peraturan yang berlaku di sekolah. Semula peserta didik malas untuk sekolah pada perkembangannya menjadi lebih rajin untuk bersekolah dan menjalankan tugas-tugas yang diberikan oleh guru, dan pelatih. Pemaparan yang dikemukakan menunjukkan teknik pendisiplinan yang dipergunakan dalam bentuk demokratis.

Pernyataan tersebut didukung dengan pernyataan dari Hadisubrata dalam Tu'u (2004: 46) menjelaskan bahwa dalam teknik disiplin demokratis dilakukan dengan cara memberikan bentuk penjelasan kepada peserta didik, serta dilakukan bentuk disikusi dan penalaran yang dapat membantu memberikan pemahaman tentang kesadaran untuk mematuhi dan menaati peraturan itu penting.

Disisi lain hasil penelitian menunjukkan bahwa teknik pendisiplinan demokratis untuk bentuk hukuman yang diberikan kepada peserta didik berdasarkan kesepakatan bersama dengan siswa. Penerapan pendisiplinan hukuman yang diberikan dilakukan dengan kesadaran bukan keterpaksaan dalam menjalankan peraturan yang berlaku dalam aktivitas mereka di tempat latihan. Pelatih 
Pola Kekuasaan Pendisiplinan dalam Membina Perilaku Peserta Didik di SMA Negeri Olahraga

Sriwijaya (Lamtarida Deasy Marice, Ridhah Taqwa)

menerapkan hukuman berdasarkan ketentuan dari peraturan yang telah disepakati bersama dan bertujuan untuk pembentukan fisik sebagai seorang atlet yang identik dengan fisik.

\section{SIMPULAN}

Berdasarkan hasil penelitian pola penerapan disiplin dalam membina perilaku peserta didik dapat terlihat dari beberapa aktivitas yang dilakukan seperti di lingkungan sekolah, tempat latihan, dan asrama sekolah yang dilakukan oleh pelaksana penerapan kedisiplinan dengan menggunakan dua bentuk mekanisme pendisiplinan. Mekanisme pendisiplinan pertama; melalui pengawasan dan pemantauan dalam bentuk sistem poin yang berfungsi sebagai panapticon yang memiliki power untuk mengawasi perilaku peserta didik dalam menjalankan aktivitas sebagai seorang siswa dan atlet. Bentuk lain dari pengawasan adalah dengan menerapkan razia. Razia merupakan bentuk pemantauan yang memberikan keefektifan untuk mengurangi terjadinya pelanggaran di SMA Negeri Olahraga Sriwijaya. Dua bentuk metode razia yang dilakukan adalah secara kontinue yang pelaksanaannya dilakukan satu bulan sebanyak satu kali dan pemantauan dari orang lain.

'Mekanisme kedua dari pola penerapan pendisiplinan adalah melalui normalisasi yang dilakukan dengan penerapan dan pemberlakukan punishment dan reward sebagai pengontrol perilaku peserta didik untuk mengoreksi, dan mengendalikan perilaku peserta didik. Penerapan punishment dapat mengelompokkan peserta didik dalam dua bentuk kelompok yaitu peserta didik yang patuh dan peserta didik yang tidak patuh.

Berdasarkan hasil penelitian ini bahwa teknik pendisiplinan yang dilakukan oleh pelaksana penerapan disiplin adalah dengan pendisiplinan demokratis. Dan di sisi lain teknik pendisiplinan otoriter perlu diterapkan kepada peserta didik. Dalam pendisiplinan, hukuman (punishment) dan penghargaan (reward) diberikan dilakukan secara proporsional. Punishment yang diberikan memiliki nilai edukatif bagi peserta didik dan bertujuan untuk menyadarkan, mengoreksi, dan mendidik dan dapat mendorong terjadinya perubahan perilaku peserta didik. Pelanggaran yang dilakukan oleh peserta didik ditindak lanjutkan dengan melibatkan unsur-unsur yang ada di sekolah, asrama, dan pelatih.

\section{UCAPAN TERIMA KASIH}

Terima kasih kepada Mitrisno, S.Pd, M.Pd, Kepala Sekolah Menengah Atas Negeri Olahraga Sriwijaya yang telah memberikan izin penelitian. Terima kasih juga disampaikan kepada Raden Den, S,Pd, M.Pd, Wakil Kepala Sekolah, Wahyono, S.Pd. selaku Guru Bimbingan konseling, dan Guru sebagai informan dalam penelitian ini.

\section{DAFTAR PUSTAKA}

Akbal, M., dan Rusnaini, E. 2016. Analisis Kepatuhan Peserta Didik Terhadap Tata Tertib Sekolah (Studi Pada SMAN 1 Penrang Kabupaten Wajo ). Jurnal Tommalebi. 3 (2). Retrieved from https://ojs.unm.ac.id/tomalebbi/article/view/2045

Ball, Kristie, Haggerty K, and Lyon D.2012.Routledge Handbook of Surveillance Studies. London and New York : Routledge Taylor and Francis Group

Bungin, Burhan. 2009. Penelitian Kualitatif: Komunikasi, Ekonomi, kebijakan Publik, dan Ilmu Sosial Lainnya. Jakarta: Kencana Prenada Media Group.

Creswell, John. W. 2017. Research Design. Pendekatan Metode Kualitatif, Kuantitatif, dan Campuran. Edisi keempat, Cetakan II. Yogyakarta : Pustaka Pelajar.

Hadiawati, Lina. 2008. Pembinaan Keagamaan Sebagai Upaya Meningkatkan Kesadaran Siswa Melaksanakan Ibadah Shalat (Penelitian Di Kelas X dan XI SMA Plus Qurrota "Ayun Kecamatan Samarang Kabupaten Garut). Jurnal Pendidikan Universitas Garut Fakultas Pendidikan Islam dan Keguruan Universitas Garut. 2 (1), 18 - 25.

Hurlock, Elizabeth. 1978. Perkembangan Anak Jilid 2 Edisi Keenam. Jakarta : Erlangga

Hardiyanta, Petrus Sunu. 1997. Michel Foucault Disiplin Tubuh. Bengkel Individu Modern. Yogyakarta: LKIS. 
Hidayat, Rakhmat. 2011. Pengantar Sosiologi Kurikulum. Jakarta: PT RajaGrafindo Persada.

Idi, Abdullah. 2014. Sosiologi Pendidikan: Individu, Masyarakat, dan Pendidikan. Jakarta: PT RajaGrafindo Persada.

Idi, Abdullah. 2015. Etika Pendidikan: keluarga, Sekolah, dan Masyarakat. Jakarta: PT RajaGrafindo Persada.

Juhji, Najihaturrohmah. 2017. Implementasi Program Boarding School Dalam Pembentukan Karakter Siswa di SMA Negeri Cahaya Madani Banten Boarding School Pandeglang. Tarbawi 3 (02). Retrieved from http://jurnal.uinbanten.ac.id/index.php/tarbawi/index

Komariah, Aan dan Satori, Djam'an. 2017. Metodelogi Penelitian Kualitatif. Bandung: Alfabeta.

Martono, Nanang. 2014. Sosiologi Pendidikan Michel Foucoult Pengetahuan, Kekuasaan, Disiplin, Hukuman, dan Seksualitas. Jakarta: PT RajaGrafindo Persada.

Martono, Nanang. 2016. Sekolah (Bukan) Penjara. Jakarta: Mitra Wacana Media.

Musyaddad, Kholid. 2013. Problematika Pendidikan di Indonesia. Edu-Bio. 4 (4) (http://ejournal.iainjambi.ac.id/index.php/edubio/article/view/378)

Pusat Pembinaan dan Pengembangan Bahasa. 1999. Kamus Besar Bahasa Indonesia. Edisi kedua. Cetakan kesepuluh. Jakarta: Balai Pustaka.

Srijatun. 2012. Pendidikan Anak Usia Dini Dalam Presfektif Islam. Jurnal At-Taqaddum. 4 (2).

Tu’u, Tulus.2004. Peran Disiplin Pada Perilasku dan Prestasi Siswa. Jakarta: Grasindo. 